\title{
Breast involvement of hematological malignancies: imaging and clinical findings
}

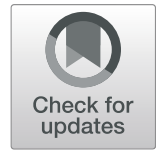

\author{
Gamze Durhan *i] and Figen Demirkazık
}

\begin{abstract}
Background: Breast involvement of hematological malignancies is a very rare entity. Accurate diagnosis is essential for appropriate treatment. The aim of this study was to clarify the clinical and radiological findings of hematological malignancy breast involvement and to describe possible pitfalls in diagnosis.

Results: The images of 20 patients with breast involvement of hematological malignancies were retrospectively evaluated on ultrasonography, mammography, and magnetic resonance imaging (MRI) and the findings were reported. Bilaterality was seen only in cases with secondary involvement, and there was no marked difference between primary and secondary breast involvement of hematological malignancies. All patients underwent ultrasonography examination. According to ultrasonography, breast masses were most frequently irregular in shape $(11 / 20,55 \%)$ with non-circumscribed margins $(11 / 20,55 \%)$. Posterior acoustic enhancement was noted in 14 cases (70\%). Posterior shadowing was not observed in any of the patients. Mammography was available in 10 patients. Microcalcification was not observed in any patient on mammography. MRI was available in four patients. Hyperintensity in T2-weighted images, type 2 or type 3 dynamic curve, and diffusion restriction were observed in all cases.

Conclusions: Hematological malignancies may mimic both benign breast lesions and breast carcinoma. Familiarity with the radiological features of hematological malignancies can help accurate diagnosis.
\end{abstract}

Keywords: Hematological malignancies, Breast, Imaging

\section{Background}

Breast involvement of hematological malignancies is very rare constituting $<1 \%$ of all breast malignancies [1, 2]. This low prevalence may be due to the scarcity of lymphoid tissue in the breast tissue. Breast hematological diseases can occur as primary or secondary. In primary disease, there is no history of extra-mammary disease or evidence of concurrent extensive disease other than ipsilateral axillary and supraclavicular lymph nodes. Secondary hematological diseases of the breast are more common and more easily diagnosed because of the history of hematological malignancy. The diagnosis of primary involvement is very difficult due to its rarity, nonspecific imaging findings, and radiological features which

\footnotetext{
* Correspondence: gamzedurhan@gmail.com

Department of Radiology, Hacettepe University Faculty of Medicine, 06410 Ankara, Turkey
}

can overlap with other breast tumors [3]. However, it is of great importance that a correct diagnosis of hematological involvement of the breast is made because treatment is different from breast carcinoma, as it does not require surgery. Furthermore, hematological diseases of the breast can mimic benign breast lesions such as hamartoma or fibroadenomas [4]. Therefore, the aim of this study was to clarify the clinical and radiological findings of hematological malignancy breast involvement diagnosed at a single institution and to describe possible pitfalls in diagnosis.

\section{Methods}

Approval for the study was granted by the Institutional Review Board. A retrospective review was made of the clinical and radiological records of 20 patients diagnosed with breast hematological malignancy pathologically

\section{Springer Open}

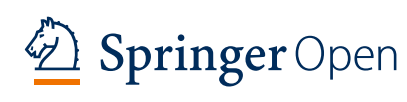

(c) The Author(s). 2021 Open Access This article is licensed under a Creative Commons Attribution 4.0 International License, which permits use, sharing, adaptation, distribution and reproduction in any medium or format, as long as you give appropriate credit to the original author(s) and the source, provide a link to the Creative Commons licence, and indicate if changes were made. The images or other third party material in this article are included in the article's Creative Commons licence, unless indicated otherwise in a credit line to the material. If material is not included in the article's Creative Commons licence and your intended use is not permitted by statutory regulation or exceeds the permitted use, you will need to obtain permission directly from the copyright holder. To view a copy of this licence, visit http://creativecommons.org/licenses/by/4.0/. 
between January 2010 and January 2021. Patients were excluded if aged $<18$ years or if at least one breast imaging was not available. The histopathological data were obtained from the pathology examination results. Pathology confirmation was performed via image-guided core needle biopsy in 18 patients and excisional biopsy in two patients.

All patients underwent ultrasonography (US) examination, mammography was applied to 10 , and magnetic resonance imaging (MRI) to 4 . All the images were interpreted by two experienced radiologists. The imaging features were described according to the American College of Radiology BI-RADS (breast imaging reporting and data system) lexicon [5].

\section{Results}

The patient characteristics are summarized in Table 1 . All the patients were female and the mean age was 49.4 \pm 19.1 years. The mean size of the lesions was $40.8 \mathrm{~mm}$. The largest mass was selected in cases with multiple lesions. The most common hematological malignancy affecting the breast was lymphoma. Of 20 patients, 15 (75\%) were classified as secondary, and five $(25 \%)$ as primary involvement of the breast by hematological diseases. In primary cases, the mean age was $54.8 \pm 23.8$ years and the mean lesion size was $35.2 \pm 28.1 \mathrm{~mm}$, and in secondary cases, the mean age was $47.6 \pm 17.9$ years and lesion size was $42.7 \pm 35.9 \mathrm{~mm}$. All the bilateral cases were secondary involvement. Pathological diagnoses were diffuse large B-cell lymphoma $(n 7)$, marginal zone lymphoma ( $n$ 5), Hodgkin lymphoma ( $n$ 2), precursor B lymphoblastic lymphoma $(n 1)$, mycosis fungoides (n 1), granulocytic sarcoma ( $n 3)$, and plasmacytoma ( $n$ $1)$. Most patients (n 14) presented with a palpable mass within the breast, while one patient was admitted for axillary palpable mass. Four of the patients were asymptomatic and were diagnosed during routine examinations. Skin thickening was detected in 12 patients, and in two of these cases, this was caused by skin invasion by the mass. Ipsilateral axillary lymphadenopathy was detected in 14 cases.

All of the patients with primary diseases presented with a breast mass and did not have any symptoms including B symptoms (fever, weight, and night sweats). The most common presenting symptom of patients with the secondary disease was swelling in the neck before breast involvement ( $n$ 7). Three patients had axillary mass, one patient with multiple myeloma had low back pain due to spine involvement, one patient with mycosis fungoides had skin lesions on the arms and back, one patient had dental pain due to maxillary bone involvement, and one patient had eye redness and decreased of vision due to ocular lymphoma. Another patient was diagnosed with gastric lymphoma while being investigated for iron deficiency anemia. At the time of diagnosis, 4 patients had B symptoms, 5 patients had elevated lactate dehydrogenase, and 2 patients had thrombocytopenia. Information about therapy and follow-up was incomplete in 4 patients. Mortality developed in 9 patients (45\%), of which 8 were secondary involvement of the breast by hematological diseases. Systemic chemotherapy was applied to 15 patients, with local radiation added in five patients. Bone marrow transplantation was performed in five patients. Immunotherapy was used to treat a patient with Hodgkin lymphoma, and Psoralen plus ultraviolet A (PUVA) was used for the treatment of mycosis fungoides.

Mammography was available in 10 patients. Breast masses were the most common appearance $(8 / 10,80 \%)$. Asymmetric density was seen in two patients. Microcalcification was not observed in any patient. Breast masses had an oval or round shape and circumscribed margins in five cases. Irregular shape and non-circumscribed margins were observed in two cases. Six of 10 cases (60\%) were hyperdense and four (40\%) were isodense. In one patient with granulocytic sarcoma and multiple lesions within both breasts, both round/circumscribed and irregular/non-circumscribed characteristics were seen.

All patients underwent ultrasonography examination. Breast masses were most frequently irregular in shape $(11 / 20,55 \%)$ with non-circumscribed margins (11/20, $55 \%)$. Posterior acoustic enhancement was noted in 14 cases (70\%), and no posterior acoustic phenomenon was seen in six cases (30\%). Posterior shadowing was not observed in any of the patients. Masses were predominantly heterogeneous (12/20, 60\%). Hyperechoic areas within the mass are seen in six cases. Color Doppler US was available in 10 patients, all of which showed hypervascularity.

MRI was available in four patients. Hyperintensity in T2-weighted images, type 2 (plateau pattern) or type 3 (wash-out pattern) dynamic curve, and diffusion restriction were observed in all cases. The mean apparent diffusion coefficient $(\mathrm{ADC})$ value was $0.585 \times 10^{-3}$.

\section{Discussion}

In this study, although bilaterality was seen only in cases with secondary involvement, no marked difference was observed between primary and secondary breast involvement of hematological malignancies. Hematological malignancies may mimic both benign breast lesions due to an oval-round shape, circumscribed margins, posterior acoustic enhancement, and breast carcinoma, especially inflammatory breast carcinoma, because of skin thickening, axillary lymphadenopathy, irregular shape, and noncircumscribed margins. The absence of microcalcification and posterior shadowing, and markedly low ADC values can differentiate breast carcinoma. 
Table 1 Clinical and radiological findings of 20 patients with breast involvement of hematological malignancies

\begin{tabular}{|c|c|c|c|c|c|c|c|c|c|}
\hline Case & Age & Pathologic type & $\begin{array}{l}\text { Primary/ } \\
\text { secondary } \\
\text { lymphoma }\end{array}$ & $\begin{array}{l}\text { Size } \\
(\mathrm{mm})\end{array}$ & Side $^{a}$ & $\begin{array}{l}\text { Axillary LAP/ } \\
\text { skin thickening }\end{array}$ & MMG & US & MRI \\
\hline 1 & 83 & $\begin{array}{l}\text { Diffuse large B-cell } \\
\text { lymphoma }\end{array}$ & Primary & 36 & Left $^{a}$ & $+/+$ & NA & $\begin{array}{l}\text { Irregular/non- } \\
\text { circumscribed } \\
\text { Hypoechoic } \\
\text { Posterior enhancement } \\
\text { Vascularity: NA }\end{array}$ & NA \\
\hline 2 & 57 & $\begin{array}{l}\text { Diffuse large B-cell } \\
\text { lymphoma }\end{array}$ & Primary & 11 & Right & $+/+$ & $\begin{array}{l}\text { Oval-round } \\
\text { Circumscribed } \\
\text { Isodense }\end{array}$ & $\begin{array}{l}\text { Oval-round/non- } \\
\text { circumscribed } \\
\text { Hypoechoic } \\
\text { Posterior enhancement } \\
\text { Hypervascularity }\end{array}$ & NA \\
\hline 3 & 37 & $\begin{array}{l}\text { Diffuse large B-cell } \\
\text { lymphoma }\end{array}$ & Secondary & 13 & Bilateral & $+/+$ & $\begin{array}{l}\text { Asymmetric } \\
\text { density } \\
\text { Isodense }\end{array}$ & $\begin{array}{l}\text { Irregular/non- } \\
\text { circumscribed } \\
\text { Hypoechoic } \\
\text { Posterior phenomena: } \\
- \\
\text { Vascularity: NA }\end{array}$ & NA \\
\hline 4 & 47 & $\begin{array}{l}\text { Diffuse large B-cell } \\
\text { lymphoma }\end{array}$ & Secondary & 160 & Left & $+/+$ & NA & $\begin{array}{l}\text { Irregular/non- } \\
\text { circumscribed } \\
\text { Heterogeneous } \\
\text { Posterior phenomena: } \\
- \\
\text { Vascularity: NA }\end{array}$ & NA \\
\hline 5 & 57 & $\begin{array}{l}\text { Diffuse large B-cell } \\
\text { lymphoma }\end{array}$ & Secondary & 47 & Right $^{a}$ & $+/-$ & $\begin{array}{l}\text { Asymmetric } \\
\text { density } \\
\text { Hyperdense }\end{array}$ & $\begin{array}{l}\text { Oval-round/non- } \\
\text { circumscribed } \\
\text { Heterogeneous }{ }^{c} \\
\text { Posterior enhancement } \\
\text { Vascularity: NA }\end{array}$ & $\begin{array}{l}\text { Dynamic curve, } 2 \\
\text { Diffusion restriction (ADC } \\
0.542 \times 10^{-3} \text { ) } \\
\text { T2-hyperintense }\end{array}$ \\
\hline 6 & 67 & $\begin{array}{l}\text { Diffuse large B-cell } \\
\text { lymphoma }\end{array}$ & Primary & 81 & Right $^{a}$ & $-/+$ & NA & $\begin{array}{l}\text { Oval-round/ } \\
\text { circumscribed } \\
\text { Heterogeneous c } \\
\text { Posterior enhancement } \\
\text { Vascularity: NA }\end{array}$ & NA \\
\hline 7 & 65 & $\begin{array}{l}\text { Diffuse large B-cell } \\
\text { lymphoma }\end{array}$ & Secondary & 22 & Bilateral & $+/+$ & $\begin{array}{l}\text { Oval-round } \\
\text { Circumscribed } \\
\text { Hyperdense }\end{array}$ & $\begin{array}{l}\text { Oval-round/ } \\
\text { circumscribed } \\
\text { Hypoechoic } \\
\text { Posterior phenomena: } \\
- \\
\text { Hypervascularity }\end{array}$ & NA \\
\hline 8 & 62 & Marginal zone lymphoma & Secondary & 30 & Left $^{\mathrm{a}}$ & $-/-$ & $\begin{array}{l}\text { Oval-round } \\
\text { Circumscribed } \\
\text { Isodense }\end{array}$ & $\begin{array}{l}\text { Oval-round/ } \\
\text { circumscribed } \\
\text { Heterogeneous c } \\
\text { Posterior enhancement } \\
\text { Hypervascularity }\end{array}$ & NA \\
\hline 9 & 69 & Marginal zone lymphoma & Secondary & 14 & Bilateral & $+/-$ & $\begin{array}{l}\text { Oval-round } \\
\text { Circumscribed } \\
\text { Hyperdense }\end{array}$ & $\begin{array}{l}\text { Oval-round/ } \\
\text { circumscribed } \\
\text { Hypoechoic } \\
\text { Posterior enhancement } \\
\text { Hypervascularity }\end{array}$ & NA \\
\hline 10 & 77 & Marginal zone lymphoma & Secondary & 54 & Left $^{\mathrm{a}}$ & $+/-$ & NA & $\begin{array}{l}\text { Irregular/non- } \\
\text { circumscribed } \\
\text { Heterogeneous } \\
\text { Posterior enhancement } \\
\text { Vascularity: NA }\end{array}$ & NA \\
\hline 11 & 48 & Marginal zone lymphoma & Primary & 13 & Right $^{a}$ & $+/+$ & NA & $\begin{array}{l}\text { Irregular/non- } \\
\text { circumscribed } \\
\text { Hypoechoic } \\
\text { Posterior enhancement } \\
\text { Hypervascularity }\end{array}$ & NA \\
\hline 12 & 55 & Marginal zone lymphoma & Secondary & 32 & Left & $+/-$ & $\begin{array}{l}\text { Irregular } \\
\text { Non- } \\
\text { circumscribed } \\
\text { Hyperdense }\end{array}$ & $\begin{array}{l}\text { Irregular/non- } \\
\text { circumscribed } \\
\text { Hypoechoic } \\
\text { Posterior enhancement } \\
\text { Vascularity: NA }\end{array}$ & $\begin{array}{l}\text { Dynamic curve, } 2 \\
\text { Diffusion restriction (ADC } \\
0.558 \times 10^{-3} \text { ) } \\
\text { T2-hyperintense }\end{array}$ \\
\hline 13 & 19 & Granulocytic sarcoma & Primary & 35 & Left & $-/-$ & NA & $\begin{array}{l}\text { Oval-round/ } \\
\text { circumscribed } \\
\text { Heterogeneous c } \\
\text { Posterior enhancement } \\
\text { Hypervascularity }\end{array}$ & NA \\
\hline
\end{tabular}


Table 1 Clinical and radiological findings of 20 patients with breast involvement of hematological malignancies (Continued)

\begin{tabular}{|c|c|c|c|c|c|c|c|c|c|}
\hline Case & Age & Pathologic type & $\begin{array}{l}\text { Primary/ } \\
\text { secondary } \\
\text { lymphoma }\end{array}$ & $\begin{array}{l}\text { Size } \\
(\mathrm{mm})\end{array}$ & Side $^{a}$ & $\begin{array}{l}\text { Axillary LAP/ } \\
\text { skin thickening }\end{array}$ & MMG & US & MRI \\
\hline 14 & 50 & Granulocytic sarcoma & Secondary & 25 & Left & $-/+$ & NA & $\begin{array}{l}\text { Irregular/non- } \\
\text { circumscribed } \\
\text { Heterogeneous }{ }^{c} \\
\text { Posterior enhancement } \\
\text { Vascularity: NA }\end{array}$ & NA \\
\hline $15^{\mathrm{d}}$ & 22 & Granulocytic sarcoma & Secondary & 47 & Bilateral & $+/+{ }^{b}$ & $\begin{array}{l}\text { Oval-round } \\
\text { Circumscribed } \\
\text { Hyperdense }\end{array}$ & $\begin{array}{l}\text { Oval-round } \\
\text { Circumscribed } \\
\text { Heterogeneous }{ }^{c} \\
\text { Posterior enhancement } \\
\text { Vascularity: NA }\end{array}$ & $\begin{array}{l}\text { Dynamiccurve, } 3 \\
\text { Diffusion restriction (ADC } \\
0.403 \times 10^{-3} \text { ) } \\
\text { T2-hyperintense }\end{array}$ \\
\hline 16 & 21 & Hodgkin lymphoma & Secondary & 40 & Bilateral & $+/+$ & NA & $\begin{array}{l}\text { Irregular/non- } \\
\text { circumscribed } \\
\text { Heterogeneous }{ }^{c} \\
\text { Posterior phenomena: } \\
- \\
\text { Vascularity: NA }\end{array}$ & NA \\
\hline 17 & 36 & Hodgkin lymphoma & Secondary & 60 & Right & $-/+$ & $\begin{array}{l}\text { Irregular } \\
\text { Non- } \\
\text { circumscribed } \\
\text { Hyperdense }\end{array}$ & $\begin{array}{l}\text { Irregular/non- } \\
\text { circumscribed } \\
\text { Heterogeneous } \\
\text { Posterior enhancement } \\
\text { Hypervascularity }\end{array}$ & NA \\
\hline 18 & 22 & $\begin{array}{l}\text { Precursor B lymphoblastic } \\
\text { lymphoma }\end{array}$ & Secondary & 42 & Right $^{\mathrm{a}}$ & $-1-$ & NA & $\begin{array}{l}\text { Irregular/non- } \\
\text { circumscribed } \\
\text { Heterogeneous } \\
\text { Posterior enhancement } \\
\text { Hypervascularity }\end{array}$ & NA \\
\hline 19 & 36 & Mycosis fungoides & Secondary & 46 & Right $^{\mathrm{a}}$ & $+/+^{\mathrm{b}}$ & NA & $\begin{array}{l}\text { Irregular/non- } \\
\text { circumscribed } \\
\text { Heterogeneous } \\
\text { Posterior phenomena: } \\
- \\
\text { Hypervascularity }\end{array}$ & NA \\
\hline 20 & 58 & Plasmacytoma & Secondary & 9 & Right $^{\mathrm{a}}$ & $+/-$ & $\begin{array}{l}\text { Oval-round } \\
\text { Circumscribed } \\
\text { Hyperdense }\end{array}$ & $\begin{array}{l}\text { Oval-round/ } \\
\text { Circumscribed } \\
\text { Hypoechoic } \\
\text { Vertical orientation } \\
\text { Posterior phenomena: } \\
\text { - } \\
\text { Hypervascularity }\end{array}$ & $\begin{array}{l}\text { Dynamic curve, } 2 \\
\text { Diffusion restriction (ADC } \\
0.840 \times 10^{-3} \text { ) } \\
\text { T2-hyperintense }\end{array}$ \\
\hline
\end{tabular}

Abbreviations: LAP lymphadenopathy, US ultrasonography, MMG mammography, MRI magnetic resonance imaging, NA not applicable, $A D C$ apparent diffusion coefficient

${ }^{a}$ Shows single lesions within the left or right breast

${ }^{\mathrm{b}} \mathrm{Skin}$ thickening is because of invasion by the mass

${ }^{c}$ Heterogeneity is due to hyperechoic areas

${ }^{\mathrm{d}}$ This patient has multiple lesions, some of which have an oval-round shape, circumscribed margins, and type 3 dynamic curve, while others show irregular shape, not-circumscribed margin, and type 2 dynamic curve

Although some previous studies have reported that primary breast lymphoma manifests at a larger size with a worse prognosis and at an earlier age than secondary breast lymphoma $[3,6]$, the current study results were the opposite of these findings. Of the total nine deaths, eight were secondary involvement of the breast. The only death from primary breast involvement was the oldest patient ( 83 years old) in the group. These differences may be a result of the fact that the current study patient group included different hematological diseases such as granulocytic sarcoma and plasmacytoma. No marked difference was observed between primary and secondary breast involvement of hematological malignancies except that bilaterality was only seen in secondary involvement. Similar to these findings, Genco et al. also reported no significant difference between patients with primary and secondary breast lymphoma [7]. The most common presenting symptoms were neck and axillary masses before breast involvement in the cases with secondary diseases, while the patients with primary breast lymphoma did not have any symptoms except breast or axillary masses. Our two patients with secondary breast involvement of hematological malignancies had thrombocytopenia at the time of diagnosis. Besides thrombocytopenia due to hematological disease, chemotherapy can cause low blood cell counts. So, radiologists should check the laboratory results before breast biopsy and be careful during a biopsy in terms of bleeding and infection in these patients. In a comprehensive literature review, it has been reported that platelet count greater than $25,000 \mu / \mathrm{L}$ 
and INR less than 2.0 are appropriate for radiological procedures such as tissue biopsy and percutaneous catheter placement [8].

Hematological malignancies may mimic benign breast lesions radiologically because of the oval-round shape, circumscribed margins, and posterior acoustic enhancement. The presence of hyperechoic areas within the masses can be even more confusing and may resemble hamartoma [4] (Fig. 1). However, a history of size increase in breast lump, axillary lymphadenopathy, and skin thickening should raise suspicion of malignancy. In contrast, similar radiological findings mimicking benign breast lesions can be seen in high-grade triple-negative breast cancers or mucinous and medullary breast carcinoma $[9,10]$. Posterior acoustic enhancement can occur in high-grade triplenegative breast cancers due to necrosis and high cellularity. Also, the rapid growth of triple-negative high-grade breast cancers can lead to low stromal reaction and consequently oval-round shape and circumscribed margins [9, $11,12]$. For similar reasons, posterior acoustic enhancement, oval-round shape, and circumscribed margins may be seen in hematological malignancies of the breast.
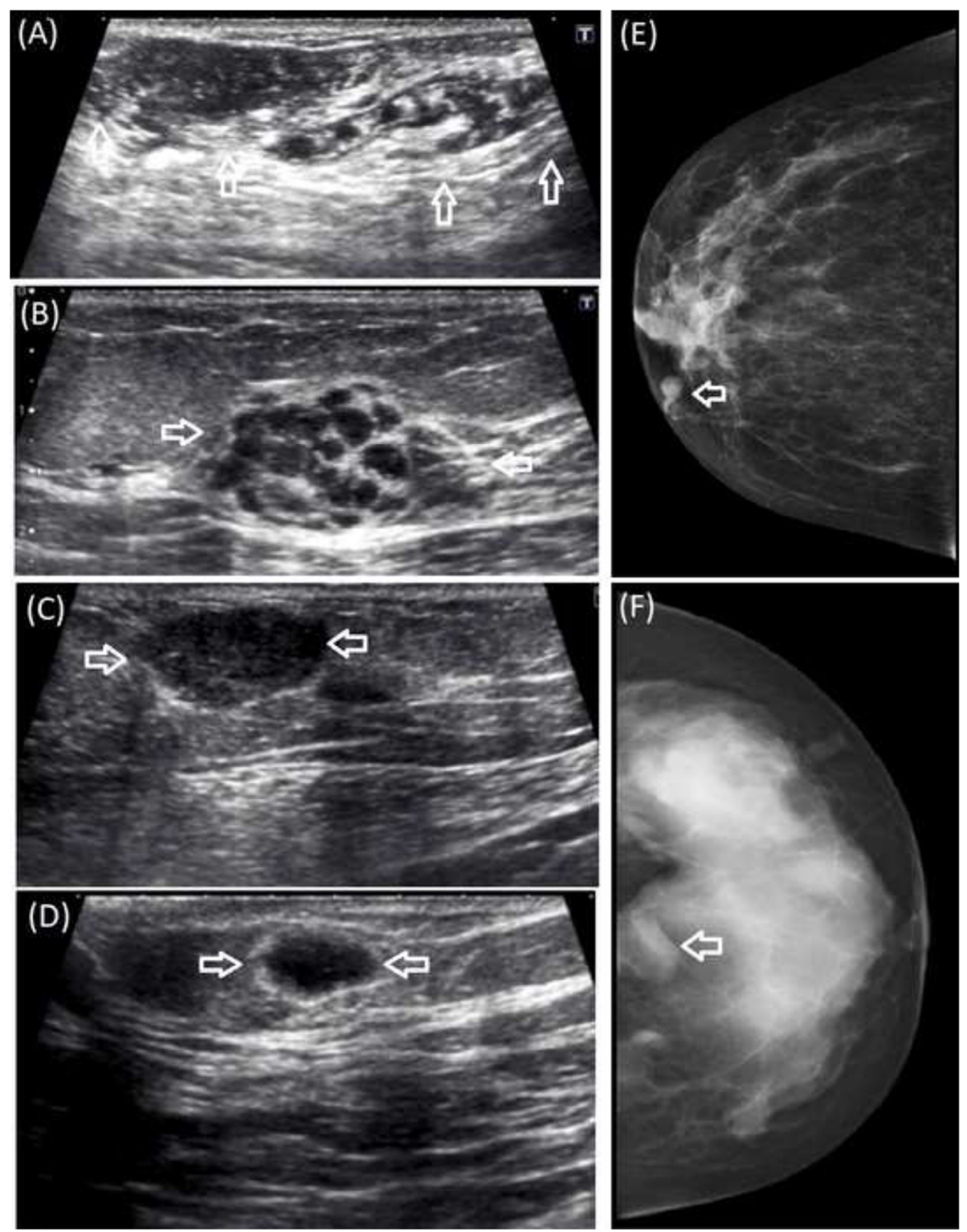

Fig. 1 Hematological malignancies mimicking benign breast lesions. US images (a-d) and mammography views (e, $\mathbf{f})$ of granulocytic sarcoma (a, b, f), lymphoma (c), and plasmacytoma (d, e) showing oval-shaped, circumscribed lesions. Posterior shadowing is not seen on US images and microcalcifications are not observed on mammography images. Hyperechoic areas can resemble hamartoma (a, b) and fibroadenoma (c, $\mathbf{d})$ can also be confused with breast involvement of hematological diseases 
Hematological malignancies may also resemble breast carcinoma, especially inflammatory breast carcinoma, because of skin thickening, axillary lymphadenopathy, irregular shape, and non-circumscribed margins (Fig. 2). Skin thickening without a mass can also be seen in patients with breast lymphoma [3]. Skin thickening can be caused by tumor involvement in the dermal lymphatics of the breast, lymphangitic metastasis to the breast, or lymphatic drainage obstruction [13]. Unlike breast cancer, posterior shadowing and microcalcification are not observed in breast involvement of hematological malignancies. Although the final diagnosis is performed histopathologically, familiarity with the radiological features of hematological malignancies can help to establish an accurate diagnosis. Misdiagnosis as breast carcinoma can result in inappropriate treatment such as breast and nodal surgery.
According to the MRI findings in this study, hematological malignancies showed T2 hyperintensity, type 2 or 3 dynamic curves, and marked diffusion restriction (Fig. 3). Hyperintensity on T2-weighted images suggests a benign lesion, while type 2 and 3 dynamic curves are usually seen in malignant lesions [14]. Dynamic curves can help to distinguish hematological malignancies from benign lesions. But, they cannot help differentiation from typical breast cancers which usually show type 2 or 3 dynamic curves. Most invasive carcinomas of the breast are hypointense or isointense relative to fibroglandular tissue. T2 hyperintensity may occur due to necrosis and inflammation associated with necrosis. Inflammation causes stromal edema within the tumor and T2 hyperintensity [15]. T2 hyperintensity can also be observed diffusely secondary to diffuse edema caused by lymphatic obstruction. Although diffusion restriction is
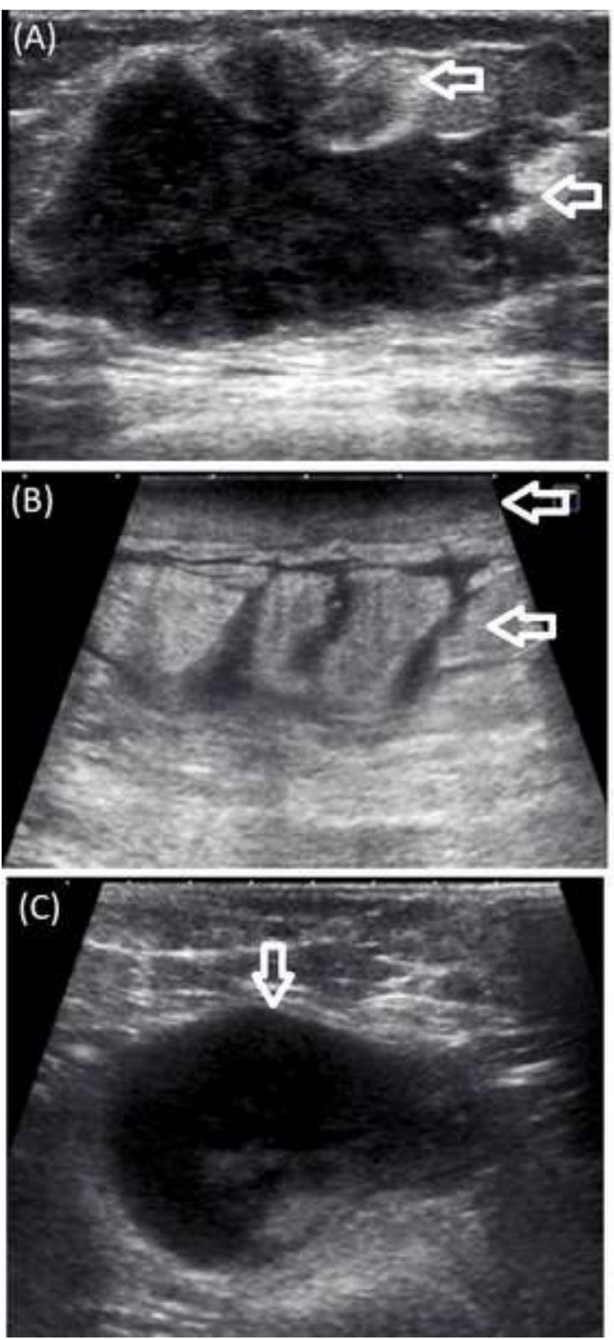

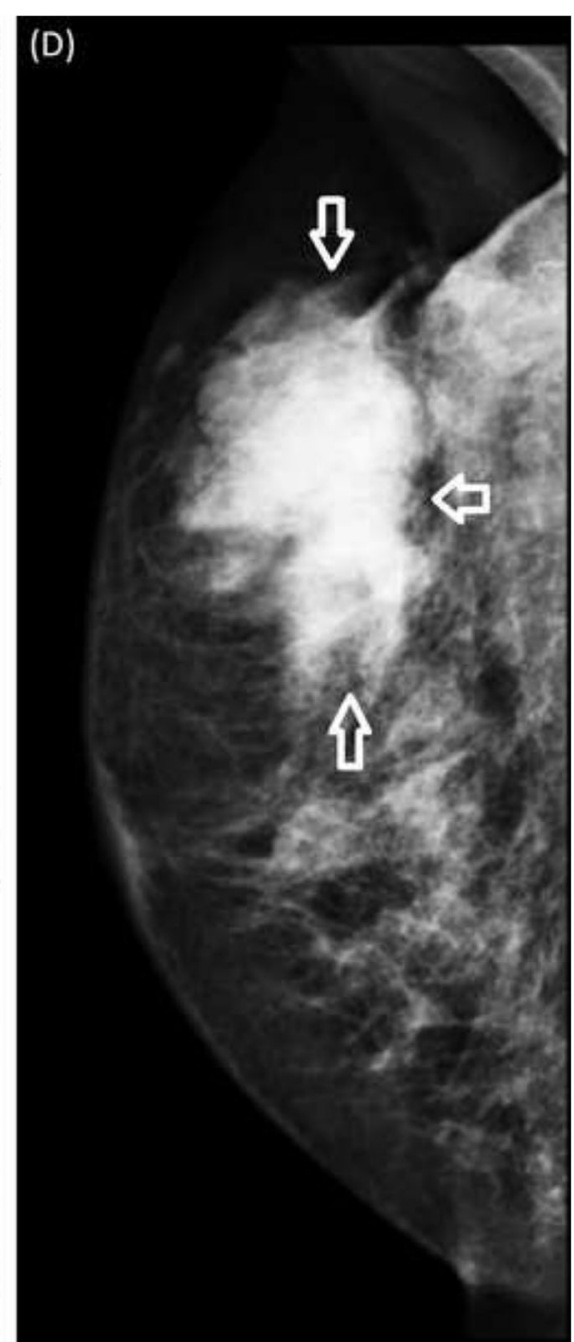

Fig. 2 Hematological malignancies mimicking malignant breast lesions. US (a) and mediolateral oblique image (d) of a patient diagnosed with lymphoma, showing an irregular-shaped, non-circumscribed lesion. Skin thickening and edema (b) and axillary lymphadenopathy (c) are seen on US images in another patient with lymphoma 

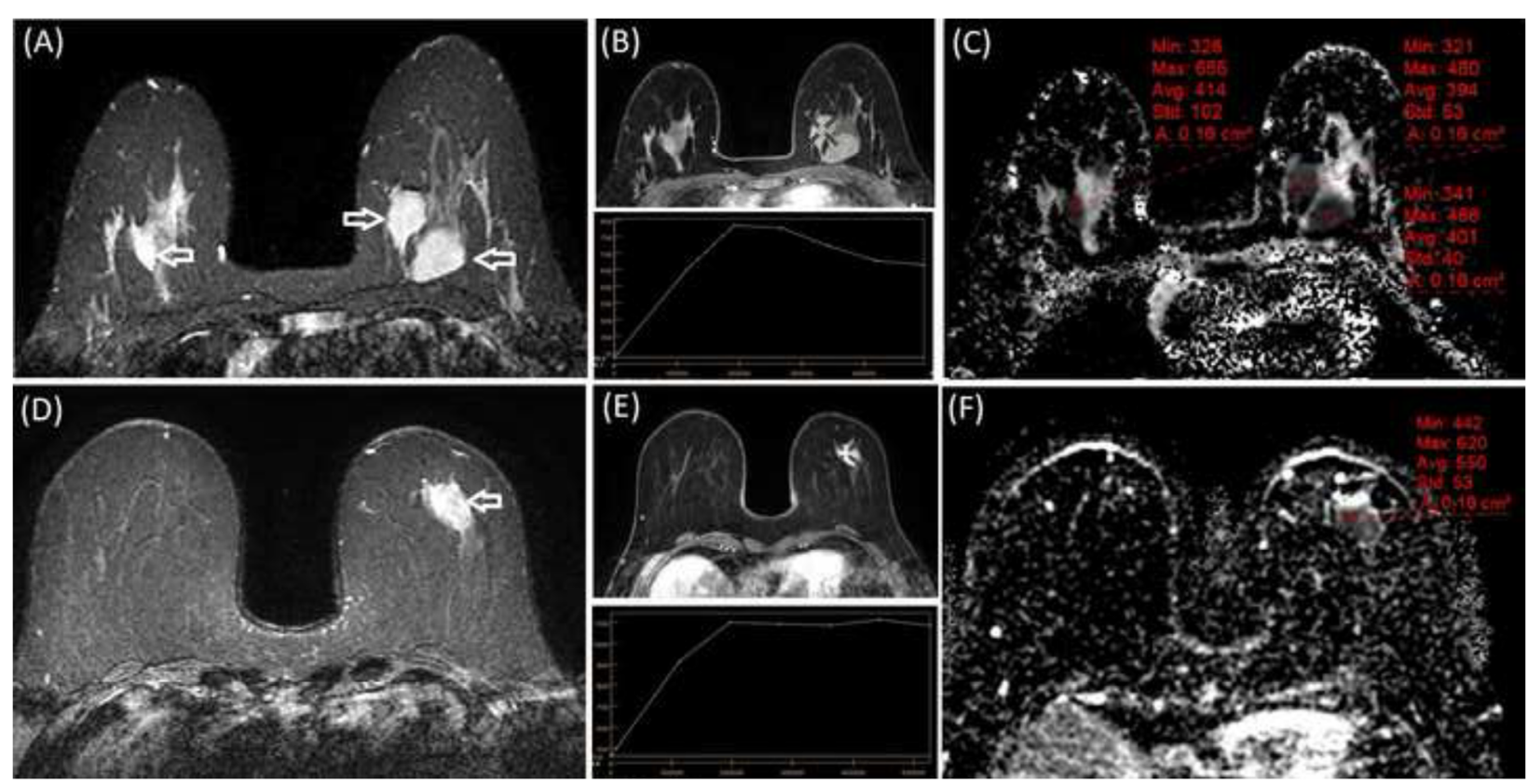

Fig. 3 MRI findings of hematological involvement of breast. Images of a 22-year-old woman diagnosed with granulocytic sarcoma show lesions in both breasts $(\mathbf{a}-\mathbf{c})$. Hyperintensity of lesions (arrows) is seen on the T2W image (a). Type 3 (wash-out) dynamic curve and contrast enhancement on contrast-enhanced T1-weighted image (b) are demonstrated. Hypointensity of lesions and low apparent diffusion coefficient (ADC) values can be seen due to diffusion restriction on the ADC map (c). MRI images of a 55-year-old woman diagnosed with marginal zone lymphoma in the left breast (d-f). Hyperintensity (arrow) is depicted on the T2W image (d). Type 2 (plateau) dynamic curve and contrast enhancement on contrastenhanced T1-weighted image (e) are demonstrated. Hypointensity of the lesion and low ADC value are seen due to diffusion restriction on the ADC map (f)

generally observed in malignant diseases, ADC values may be lower in hematological diseases compared to breast cancer. Similar to the findings of Zhou et al. [6], the current study ADC values in hematological diseases (mean ADC $0.585 \times 10^{-3}$ ) were lower than the ADC values reported in published literature for breast carcinoma (ranging from 0.9 to $1.2 \times 10^{-3}$ ) $[16,17]$. This result may have been due to the hypercellularity and small extracellular spaces of hematological malignancies. Compared to typical breast cancers, very low ADC values and T2 hyperintensity may suggest hematological malignancies.

There were some limitations of the current study. The major limitation was the limited number of cases due to the rarity of breast involvement of hematological malignancies. Secondly, our study was a retrospective study. Because of the retrospective nature of it, all imaging features including Doppler and mammography were not applicable for all patients. Finally, some clinical data such as follow-up were missing due to retrospective design.

\section{Conclusions}

In conclusion, familiarity with the radiological features of hematological malignancies can help accurate diagnosis, which is very important for appropriate treatment. Although bilaterality was seen only in cases with secondary involvement, no marked difference was observed between primary and secondary breast involvement of hematological malignancies. Hematological malignancies may mimic both benign breast lesions due to the ovalround shape, circumscribed margins, and posterior acoustic enhancement, and breast carcinoma, especially inflammatory breast carcinoma, because of skin thickening, axillary lymphadenopathy, irregular shape, and noncircumscribed margins. The absence of microcalcification and posterior shadowing, and markedly low ADC values can help in the differentiation from breast carcinoma.

\section{Abbreviations}

US: Ultrasonography; MRI: Magnetic resonance imaging; BI-RADS: Breast imaging reporting and data system; ADC: Apparent diffusion coefficient; PUVA: Psoralen plus ultraviolet A

\section{Acknowledgements \\ Not applicable}

\section{Authors' contributions}

The corresponding author (GD) wrote the article. Both GD and FD have made substantial contribution to the conception and design of the study. GD and FD have collected and interpreted data together. All authors have read and approved the submitted version of the manuscript.

\section{Funding}

This research received no specific grant from any funding agency in the public, commercial, or not-for-profit sectors. 
Availability of data and materials

Data can be shared.

\section{Declarations}

\section{Ethics approval and consent to participate}

Approval for the study was granted by Hacettepe University Ethics Committee. Project number: GO 21/355. Decision number: 2021/06-51. Informed consent was waived due to the retrospective nature of the study.

\section{Consent for publication}

Not applicable.

\section{Competing interests}

The authors declare that they have no competing interests.

Received: 23 April 2021 Accepted: 7 July 2021

Published online: 15 July 2021

\section{References}

1. Masood S (2012) Characteristics of systemic diseases in the breast: clinical, imaging and pathologic features. Womens Health (Lond) 8(5):593-599. https://doi.org/10.2217/WHE.12.45

2. Guilbert MC, Hornick JL, Chikarmane SA, Lester SC (2019) Hematologic malignancies of the breast: a contemporary series investigating incidence, presentation, accuracy of diagnosis on core needle biopsy, and hormone receptor expression. Breast Cancer (Auckl) 13:1178223419830982

3. Raj SD, Shurafa M, Shah Z, Raj KM, Fishman MDC, Dialani VM (2019) Primary and secondary breast lymphoma: clinical, pathologic, and multimodality imaging review. Radiographics 39(3):610-625. https://doi.org/10.1148/rg.201 9180097

4. Gomaa W, Ghanim A, Emam E, Bayoumi K, Ghanim A (2018) Primary myeloid sarcoma of the breast: a case report and review of literature. J Microsc Ultrastruct 6(4):212-214. https://doi.org/10.4103/JMAU.JMAU_15_18

5. D'Orsi CJSE, Mendelson EB, Morris EA et al (2013) ACR BI-RADS ${ }^{\otimes}$ Atlas, Breast Imaging Reporting and Data System. Reston, American College of Radiology

6. Zhou C, Lv K, Lin D, Yu Y, Xu M, Bu Y (2019) Radiological analysis of breast lymphoma: experiences from cases series studies. Medicine (Baltimore) 98 (48):e18101. https://doi.org/10.1097/MD.0000000000018101

7. Genco IS, Gur H, Hajiyeva S (2021) Lymphoma of the breast: a clinicopathologic analysis of 51 cases with a specific emphasis on patients with a history of breast carcinoma. Breast J 27(5):456-460. https://doi.org/1 $0.1111 /$ tbj.14198

8. O'Connor SD, Taylor AJ, Williams EC, Winter TC (2009) Coagulation concepts update. AJR Am J Roentgenol 193(6):1656-1664. https://doi.org/10.2214/AJR. 08.2191

9. Gao B, Zhang H, Zhang SD, Cheng XY, Zheng SM, Sun YH, Zhang DW, Jiang Y, Tian JW (2014) Mammographic and clinicopathological features of triplenegative breast cancer. Br J Radiol 87(1039):20130496. https://doi.org/10.12 59/bjr.20130496

10. Harvey JA (2007) Unusual breast cancers: useful clues to expanding the differential diagnosis. Radiology 242(3):683-694. https://doi.org/10.1148/ra diol.2423051631

11. Durhan G, Azizova A, Onder O, Kosemehmetoglu K, Karakaya J, Akpinar MG, Demirkazik F, Uner A (2019) Imaging findings and clinicopathological correlation of breast cancer in women under 40 years old. Eur J Breast Health 15(3):147-152. https://doi.org/10.5152/ejbh.2019.4606

12. Wojcinski S, Stefanidou N, Hillemanns P, Degenhardt F (2013) The biology of malignant breast tumors has an impact on the presentation in ultrasound: an analysis of 315 cases. BMC Womens Health 13(1):47. https://doi.org/10.11 86/1472-6874-13-47

13. Kwak JY, Kim EK, Chung SY, You JK, Oh KK, Lee YH, Kwon TH, Jung HK (2005) Unilateral breast edema: spectrum of etiologies and imaging appearances. Yonsei Med J 46(1):1-7. https://doi.org/10.3349/ymj.2005.46.1.1

14. Stusińska M, Szabo-Moskal J, Bobek-Billewicz B (2014) Diagnostic value of dynamic and morphologic breast MRI analysis in the diagnosis of breast cancer. Pol J Radiol 79:99-107. https://doi.org/10.12659/PJR.889918

15. Westra C, Dialani V, Mehta TS, Eisenberg RL (2014) Using T2-weighted sequences to more accurately characterize breast masses seen on MRI. AJR Am J Roentgenol 202(3):W183-W190. https://doi.org/10.2214/AJR.13.11266
16. Ei Khouli RH, Jacobs MA, Mezban SD, Huang P, Kamel IR, Macura KJ, Bluemke DA (2010) Diffusion-weighted imaging improves the diagnostic accuracy of conventional 3.0-T breast MR imaging. Radiology 256(1):64-73. https://doi.org/10.1148/radiol.10091367

17. Bogner W, Gruber S, Pinker K, Grabner G, Stadlbauer A, Weber M, Moser E, Helbich TH, Trattnig S (2009) Diffusion-weighted MR for differentiation of breast lesions at 3.0 T: how does selection of diffusion protocols affect diagnosis? Radiology 253(2):341-351. https://doi.org/10.1148/radiol.2532081 718

\section{Publisher's Note}

Springer Nature remains neutral with regard to jurisdictional claims in published maps and institutional affiliations.

\section{Submit your manuscript to a SpringerOpen ${ }^{\circ}$ journal and benefit from:}

- Convenient online submission

- Rigorous peer review

- Open access: articles freely available online

High visibility within the field

- Retaining the copyright to your article

Submit your next manuscript at $\boldsymbol{\nabla}$ springeropen.com 